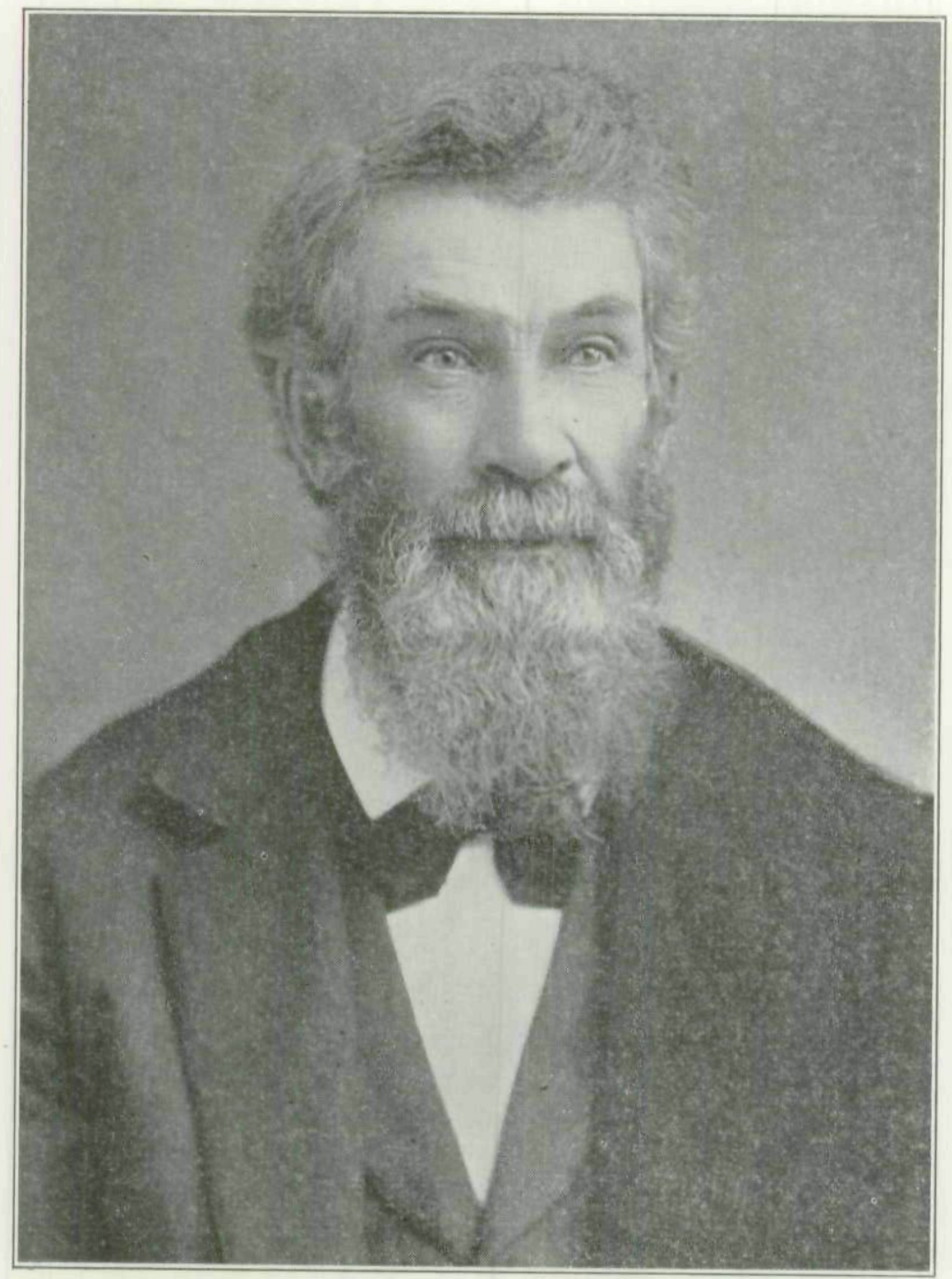

WILLIAM ALEXANDER WILSON 


\title{
BUFFALO WALLOWS AND TRAILS IN BLACK HAWK COUNTY
}

\author{
By Ellis E. Wirson
}

A narration of the existence and migrations of the herds of buffalo, bison americanus, that once roamed the plains of the mid-continent would make a romantic epic of animal life. Never has there existed a more numerous or hardier species of the bovine family, nor one in which instinctive fellowship was stronger. That centuries ago herds did traverse Iowa prairies is evidenced by their skulls, horns and parts of skeletons found in many counties. There is in addition to fossil proof, confirmatory data in wallows, trails and other marks which once existed. Alone the petrifications found scarcely warrant the assumption that large herds similar to those on the western plains at some period occupied Iowa. A plausible theory would be that blizzards drove scattered bands from their habitat in the Dakotas into the state or stragglers wandered east of the Big Sioux valley. Possibly abundant corroborative evidence did exist to warrant the assertion of extensive occupation before agrarians took possession of the land and with breaking plows destroyed the attesting marks. This occurred before observant men who understood and could interpret wild life records came upon the scene.

This legendary sketch is based mostly upon statements made by my father, William Alexander Wilson, who came to Iowa from Yadkin County, North Carolina, about 1855, then about twenty-one years of age, over six feet tall and often called Long Wilson. He lived with kin at New Providence, Hardin County, and later at Eldora, Steamboat Rock, Rockdale, now a part of Iowa Falls, Algona, Oskaloosa, and Waterloo. Between the years of 1855 and 1865 he traveled over the state mostly on foot, often on horseback, from the Mississippi rapids near Keokuk to the Big Sioux valley in the Northwest. He resided in Kossuth county at the time of the Spirit Lake massacre in March, 1857. He hauled merchandise by team from Dubuque for his store in Algona. A close observer of nature during his peregrinations, he learned to know and prize the history of wild life on the prairies, and became skillful in interpreting species and orders 


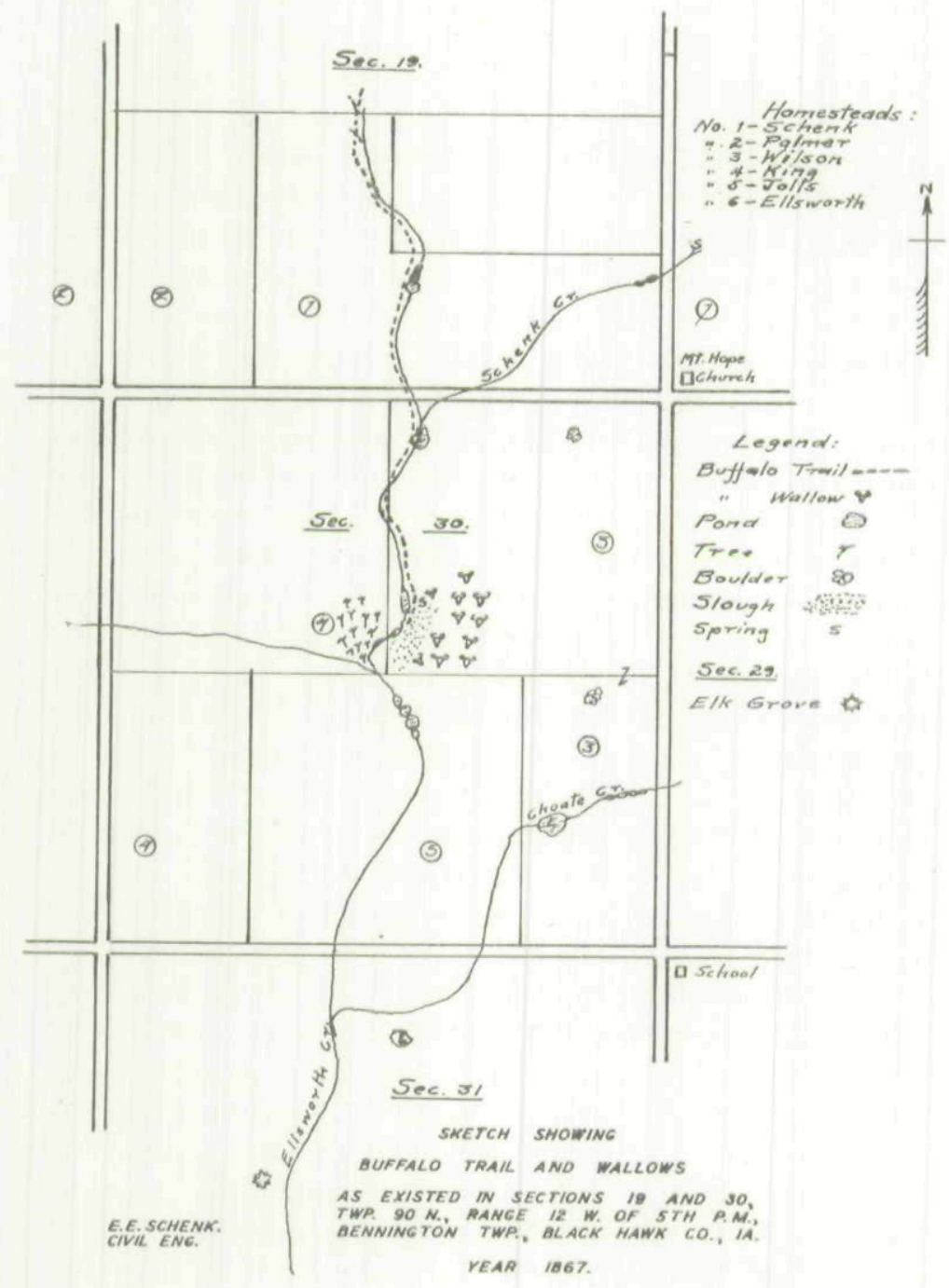


from records they had made in and on the soil and the wild groves. When at night they stalked or prowled around his homestead cabin on Black Cat Creek in Kossuth County, he often said he was able to distinguish the kind by the sound of their footfalls. To him the prairies and woods, hills and valleys, were variously autographed or labelled with animal lore. Vestiges of characteristic outlines still understandable existed in the sod. They were nature's symbolic testimony regarding ages previous, still legible. He said intelligible records regarding the buffalo were numerous when the pioneers broke the sod, but virile men were too busy with their farm duties to take notice of animal coverts or give any attention to trails and wallows.

About 1865 father purchased the northeast quarter of section thirty in Bennington Township, Black Hawk County, and established thereon his lifelong home. David W. Jolls entered land from the government in 1854 and with his parents were the first settlers in the little valley. At the center of the section he planted a cottonwood sprout which surviving grass fires and other vicissitudes stands today like a lone flagstaff, being more than sixty feet in height with a cluster of leafy branches at its top. At that date, 1854, the public highways in Bennington Township were not established and some farm buildings were erected by $\mathrm{Mr}$. Jolls near the center of section thirty. About 1870 William H. Palmer cleared a sandy tract of hazel brush located some twenty rods northwest of the center of the section. It bore traces of having been a stomping and flybrush ground for wild life. Later the tract was planted with white pine trees which are now over fifty feet high, an ever verdant landmark in the community.

Running from the north to the south near the center of the section, was a spring-fed prairie stream supplied by water bubbling softly forth from its bottom. Now for seventy years the waters have quenched the thirst of the white man and his beasts. The long spring is the never failing supply source of Ellsworth Creek, which was a clear silvery flowing brook in pioneer days. The watercourse is southward into section thirtyone onto sandy and gravelly soil where it sinks. A dry run channel carries the surface water to the Cedar River at Waterloo, where the streams is known as Virden Dry Run.

In the early days a channel extended a mile or more north of 
the spring connecting numerous small lakes mostly filled with surface water. They were peat-rimmed reservoirs and lilydecked pickerel ponds, breeding places for swarms of gnats, mosquitoes, square-eyed greenhead flies, and other insect pests. Northeast of the spring was a level meadow, the grass always very green in the summer time for only a few inches below the surface cool water stood. A quicksand reservoir that fed the long dry bank spring which never froze over in the winter.

Several miles northward a level short grass range extended to the southerly edge of the Big Woods in Bremer County. In loealities upon this smooth savanna grew a variety of native grass which matured early in summer, naturally curing like hay, retaining its nutritive qualities and unlike the slough growth which possessed little food value after being frosted. The expanse was a ten mile sweep of prairie land from the south border of the Big Woods to the Wilson spring.

Previous to 1865 shallow paths were discernible on this range which was or later became the homes of M. Farrington, Elias J. Messinger, Caspar Reinhart, Henry Faust, Michael Besh, Conrad Fritz, Henry Burk, John Nolting, W. W. Hutton, Henry Graham, Uriah Du Bois, Horatio Sage, and Nathan Beebe. These paths to the southward converged into a well defined trail along the creek's course and around the ponds on the farm of Joseph Schenk.

Passing farther south onto the Wilson land, the trail became a deep worn track about twelve inches wide and four to ten inches deep. In boggy places its course followed around tussocks, but always when passable close to the channel. Before reaching the spring there was a mile of well defined path in the sod. All made a picture pageant of animal life on the prairies, etched by mobile feet into the turf and deeper soil. The trail ended at the spring.

In 1865 southeast of the long spring was a swale quite level of about ten acres. A sort of shallow bayou was separated from the main channel of the stream by a sandy ridge.

The swale acreage was dotted with little ponds about four feet wide and five feet long with an average depth of two feet. When rain or snow water filled the depressions, the overflow ran southward into Ellsworth Creek. In the spring, or autumn when 
all the prairie sward was burned away clean, the expanse appeared in the bright sunlight like a cluster of miniature lakes. When there was a new growth of grass in the summer time the landscape was spotted. In the depressions there thrived a rank dark green slough grass while the intervening space of dry soil was covered with blue joint of a lighter shade. Rushes and cattails grew in some of the deeper pools, which seldom joined, each one being distinct and separate. Many pieces of fire burnt and sun-dried bones lay on the arid ground but only a few in the water-filled wallows.

Long dark blue flint arrowheads and spear points of a pinkish white color were found in this vicinity. An Indian fishhook made of flint with the hook part broken off was picked up near the stream.

Early in the spring of 1867 my older brother, Barnette A. Wilson, and I were assisting father in digging granite boulders, commonly called niggerheads, out of the land close to the swale that was suitable for cultivation. Having lifted a very large stone with the aid of a log chain, stone boat and horses, a deep hole was left in the ground. Father said, "Now, boys, before we fill the hole, you pick up all the pieces of bone from around the buffalo wallows and put them into it. In the fall when I cut the grass for hay they may break the sickle." While father spaded the sod away from other boulders, brother and I playfully worked gathering the pieces of hardened bones and threw them into the excavation. We raced all over the wallow site, each trying to get the biggest and cleanest bones. Father ceased his work to rest, and told us the origination of the wallows. There were nearly a hundred of them. After more than sixty years, I recall his statements to have been about as follows:

"The wallows were made by herds of buffalo that roamed over the prairies many years previous; that they undoubtedly came to the long spring to drink; that often in dry seasons when good water was scarce they would travel long distances in single file to find cold water like that in the spring; that the Indians hiding in the tall grass perhaps surprised and killed them in or near the wallows.

"When the hot days of summer came, bloodsucking insects swarmed over the herds; then the buffaloes sought out soft 
places in the sod where their feet would sink into the mire and by stomping, dug holes in which they lay to protect their bodies; that the buffalo was a vicious fellow, naturally ugly and continually bellowing and fighting; when pestered by multitudes of various kinds of insects they often became furious, and stalked around roaring with rage; that at the wallowing place each one occupied a black soil mudhole of sufficient depth to cover the legs and thin skinned parts of their bodies with only their shaggy haired heads, a long beard hanging from the under jaw, and their wooly backs exposed; that in the mire they squirmed and twisted while fighting the insects; that undoubtedly the buffalo had in years long past made the wallows where we had just gathered the bones; that after the white man appeared with his noisy and deadly guns, they vanished; that when sharp hoofs no longer cultivated the bottom of the wallows, the slough grass took root and the cat-tails and the rushes appeared, the seed having been blown by the winds or carried by the waterfowls.

"The short grass ridge located between the spring and the wallows appeared to be a rendezvous for thousand legged worms, the big brown red-winged grasshoppers, glowworms, fireflies, spotted water adders and rattlesnakes.

"Likewise the ridge was a favorite haunt for flocks of cowbirds which sang no songs but just chirped and fussed their feathers and seemed to be waiting for the return of their sociable and long-lost friend, the buffalo. The red-winged blackbird nested in clumps of willows along the creek and hatched the eggs and reared the tricky cowbird's families as well as their own."

During the autumn of the same year, 1867, the wild meadow north of the spring was mown for the first time. Fringed skyblue gentians were the only flowers growing there with the grass. A revolving wooden, horse-drawn, rake was used for windrowing, an unsuitable farm implement for rough ground. Father said, "Boys, take the hand rakes and gather the seattered hay from along the trail, for the buffaloes will not be here the coming winter to eat it. They are gone forever."

Questioned about the deepworn path and the buffalo, father said it was a trail made as they traveled single file from the feeding range at the north to the spring, the wallows and the hazelbrush patch; that there was a sort of freemasonry among 
buffaloes, which all understood and they followed an acknowledged leader who became commander through superior fighting; sometimes an ebony horn was broken off in battling.

Wild canvasback and teal ducks nested around the ponds and wallows as late as 1870 .

Mink and muskrat were numerous along the stream. Trapping and selling the pelts furnished the farmer lads spending money. A neighbor boy came to District No. 9 in December, 1867, the first term in the new one-room schoolhouse, wearing a minkskin cap. All the other boys wore cloth caps. Hectored because he had to wear a fur cap, he countered with, "Daniel Boone wore a coonskin cap and mink is nicer than coon."

In June, 1868, one mile to the sonth and near the center of section thirty-one, owned by Jeremith Ellsworth, the head, horns and parts of the skeleton of a very large elk, were uncovered by a breaking plow. My mother's brother, John Lawrence, who lived in Waterloo and vicinity from 1857 to 1870 , often hunted big game in Nebraska, Kansas and Indian Territory and he stated that small bands of elk, deer and antelope were often found mingling with the big herds of buffalo, apparently seeking protection from the fierce coyotes.

After being used as a pasture for a half century, the swale acreage was drained and plowed for the first time in 1918, also levelled, obliterating the last visible trace of the wallows.

In August, 1916, at the boggy locality where the water of Ellsworth Creek, through Virden Dry Run, flows into the Cedar River at Waterloo, H. A. Maine, contractor, while exeavating for the electric power plant found, some twenty feet below the surface, a large buffalo skull, three leg bones, eight ribs and three vertebra fossils. They are now in the H. W. Grout museum in the Black Hawk County Court House.

September 3, 1931, Levi L. Jolls, eighty-nine years of age, who lived in the valley with his parents in 1856, stated that there were no herds of domestic cattle or horses ranging the prairies in that neighborhood previous to 1870 large enough to make toe paths in the tough fibre of the sod which had been accumulating for centuries.

B. F. Gue in his "History of Iowa," speaking of wild life said, "The well worn paths of these early inhabitants of the wild 
groves, and boundless prairies were found along the banks of rivers and creeks."

Personally, I never saw in Iowa a wild buffalo weltering in a wallow or horning and pawing on a dusty knoll; never heard one roaring his vehement rage against tormenting insects, or saw the sociable cowbirds sitting on the buffaloes' backs, catching flies; never viewed a herd in the distance travelling single file following a master buffalo towards a feeding range, drinking pool, wallow or dusting hillock. However, about 1867, I did see and walk barefooted in what was unquestionably considered to be buffalo tracks deep worn below the grassy surface, and often waded in the little water-filled ponds which were perhaps a century or more previous their muddy wallows, the bath tubs and paint pots of the mighty animal monarchs of Iowa's prairies.

\section{MEDICAL NOTICE}

Having had but little practice in the treatment of western diseases, and being desirous of becoming acquainted with their nature, and best mode of treatment, I solicit a share of public patronage. As I have never experienced much difficulty in treating the various maladies incident to the human family, in eonsequence of my not understanding their nature, I would wish to be puzzled as little as possible with all other diseases, excepting ague and fever. The chief calamities of life generally fall upon the poor, therefore I solicit none of their patronage; but I am the humble servant of the wealthy part of the community because there is some prospect of obtaining a reward for my services.-Dr. S. Rogers.-Advertisement in Keokuk Register, Keokuk, Iowa, June 5, 1847. (In the Newspaper Division of the Historical, Memorial and Art Department of Iowa.) 
Copyright of Annals of Iowa is the property of State of Iowa, by \& through the State Historical Society of Iowa and its content may not be copied or emailed to multiple sites or posted to a listserv without the copyright holder's express written permission. However, users may print, download, or email articles for individual use. 